\title{
Effect of long-term natural aging on microstructure and room temperature superplastic behavior of UFG/FG Zn-Al alloys processed by ECAP
}

\author{
M. Demirtas ${ }^{1}$, H. Yanar ${ }^{2}$, G. Purcek ${ }^{2, \dagger}$ \\ 'purcek@ktu.edu.tr \\ ${ }^{1}$ Department of Mechanical Engineering, Bayburt University, Bayburt 69000, Turkey \\ ${ }^{2}$ Department of Mechanical Engineering, Karadeniz Technical University, Trabzon 61080, Turkey
}

\begin{abstract}
Two potential superplastic compositions of $\mathrm{Zn}-\mathrm{Al}$ alloy systems, $\mathrm{Zn}-22 \mathrm{Al}$ and $\mathrm{Zn}-0.3 \mathrm{Al}$ alloys, were chosen and processed by equal-channel angular pressing/extrusion (ECAP/E) in order to achieve high strain rate (HSR) superplasticity at room temperature (RT). ECAP-processed samples of both alloys were then subjected to long-term natural aging up to 1100 days to evaluate the effect of long-term natural aging on their microstructures and superplastic behaviors. Before natural aging, the maximum elongations to failure at RT were $400 \%$ for ultrafine-grained (UFG) Zn-22Al at the strain rate of $5 \times 10^{-2} \mathrm{~s}^{-1}$ and $1000 \%$ for fine-grained (FG) $\mathrm{Zn}-0.3 \mathrm{Al}$ at the strain rate of $1 \times 10^{-4} \mathrm{~s}^{-1}$. Long-term natural aging did not cause a significant change in the elongation of UFG Zn-22Al alloy with 355\% maximum elongation. However, optimum strain rate giving the maximum elongation decreased to $3 \times 10^{-3} \mathrm{~s}^{-1}$. On the other hand, $\mathrm{Zn}-0.3 \mathrm{Al}$ alloy lost more than half of its superplastic elongation and showed an elongation to failure of $435 \%$ at the end of the natural aging period of 1100 days. Microstructural analyses show that grain boundary corrosion occurred in dilute $\mathrm{Zn}-0.3 \mathrm{Al}$ alloy during the natural aging process. Corroded grain boundaries resulted in cavity nucleation during the tensile tests and some of these cavities attained large sizes and caused premature failure.
\end{abstract}

Keywords: room temperature superplasticity, $\mathrm{Zn}$ - $\mathrm{Al}$ alloys, natural aging, ultrafine-grained materials, ECAP.

\section{Introduction}

Superplasticity is described as high tensile elongations achieved in polycrystalline materials when some microstructural and experimental requirements are fulfilled. To achieve superplasticity, firstly the material should have fine-grained (FG) microstructure having grain size less than $10 \mu \mathrm{m}$. Also it should be deformed at high temperature (above $0.5 T_{\mathrm{m}}$ ) and at low strain rates (between $1 \times 10^{-5}-1 \times 10^{-3} \mathrm{~s}^{-1}$ ) $[1,2]$. However, it is also well known that superplastic behavior can be achieved at lower temperature and higher strain rates when grain size of a material is refined further. Furthermore, recent studies have shown that some materials exhibit superplastic behavior even at room temperature (RT) if grain sizes are decreased down to sub-micron levels [3-19]. Although RT superplasticity was reported in some $\mathrm{Sn}-\mathrm{Bi}$ [3], Pb-Tl [4], Pb-Sn [5] and Mg alloys [6], binary $\mathrm{Zn}-\mathrm{Al}$ alloy system is one of the well-known and most commonly studied one for this purpose [7-19]. In this alloy system, RT superplasticity was achieved in dilute $\mathrm{Zn}-\mathrm{Al}$ alloys [7 - 9], eutectic $\mathrm{Zn}-5 \mathrm{Al}$ [10] alloy and eutectoid Zn-22Al [11-19] alloy. Particularly, eutectoid Zn-22Al alloy is used as a model superplastic material to understand superplasticity and superplastic deformation mechanisms. Besides being a model superplastic material, $\mathrm{Zn}-22 \mathrm{Al}$ alloy was also proposed to be used as a seismic damper material by some researchers [12, 20-22]. Regarding such an application, it is clear that microstructural stability of the alloy and maintaining the superplastic behavior during its usage are important parameters that should be considered. Because, any possible excessive grain growth could affect the superplastic behavior of this alloy adversely. Regarding all $\mathrm{Zn}$-Al alloys exhibiting superplasticity at RT, microstructural stability is also important during their storage at RT since RT is equal to almost half of the melting point of these alloys. Therefore, it is important to evaluate the effect of long-term natural aging on their microstructures and superplastic behaviors. Previous studies have shown that natural aging caused grain growth and adversely affects the grain boundary characteristics of $\mathrm{Zn}-\mathrm{Al}$ alloys. However, there are limited studies investigating the effect of the natural aging (also known as self-annealing) process on superplastic behavior of $\mathrm{Zn}$-Al alloys [23-26]. Therefore, $\mathrm{Zn}$-Al alloys, namely eutectoid $\mathrm{Zn}-22 \mathrm{Al}$ and dilute (or quasi-single phase) $\mathrm{Zn}-0.3 \mathrm{Al}$ alloys, were processed through equal-channel angular pressing (ECAP) in order to achieve superplasticity at RT. ECAP-processed samples of both alloys were then subjected to long-term natural aging at RT up to 1100 days to evaluate the effect of long-term natural aging on their microstructures and superplastic behavior. 


\section{Methodology}

Eutectoid $\mathrm{Zn}-22 \mathrm{Al}$ and dilute $\mathrm{Zn}-0.3 \mathrm{Al}$ alloys were prepared by gravity casting method. The alloy ingots were subjected to homogenization for $24 \mathrm{~h}$ at $375^{\circ} \mathrm{C}$ for $\mathrm{Zn}-22 \mathrm{Al}$ and $320^{\circ} \mathrm{C}$ for $\mathrm{Zn}-0.3 \mathrm{Al}$ alloys. Then $13 \times 13 \times 130 \mathrm{~mm}^{3}$ dimensioned billets for ECAP processes were extracted from the homogenized ingots by machining and then exposed to a second homogenization for $48 \mathrm{~h}$ at the given temperatures followed by quenching into water. Two-step ECAP process was applied to $\mathrm{Zn}-22 \mathrm{Al}$ alloy in which the alloy was subjected to four passes at $350^{\circ} \mathrm{C}$ followed by four more passes at RT using route $\mathrm{Bc}$. Six passes of ECAP were applied to the $\mathrm{Zn}-0.3 \mathrm{Al}$ alloy at RT following a hot rolling step performed at $100^{\circ} \mathrm{C}$ with a reduction in thickness of $35 \%$. Route A was followed in the ECAP processing of $\mathrm{Zn}-0.3 \mathrm{Al}$ alloy. ECAP processes were applied to both alloys at an extrusion speed of $1 \mathrm{~mm} / \mathrm{s}$ using a die having $90^{\circ}$ internal die angle. ECAP-processed samples of both alloys were then subjected to aging at RT up to 1100 days to evaluate the effect of long-term natural aging on their microstructures and superplastic behavior.

Microstructures of the ECAP-processed and naturally aged alloys were analyzed using scanning electron microscope (SEM) and transmission electron microscope (TEM) facilities. SEM analysis samples were grinded, polished and then etched in a solution involving $5 \mathrm{~g} \mathrm{CrO}_{3}, 0.25 \mathrm{~g} \mathrm{Na}_{2} \mathrm{SO}_{4}$ and $100 \mathrm{ml} \mathrm{H}_{2} \mathrm{O}$. TEM analyses were performed using an FEI Tecnai F20 microscope operated at a nominal voltage of $200 \mathrm{kV}$. TEM samples with $500 \mu \mathrm{m}$ thickness were thinned electrochemically to form a foil by putting into a solution having $25 \% \mathrm{H}_{3} \mathrm{PO}_{4}, 25 \% \mathrm{C}_{2} \mathrm{H}_{5} \mathrm{OH}$, and $50 \% \mathrm{H}_{2} \mathrm{O}$ and applying 20-22 V potential difference.

Tensile tests were conducted at RT for evaluation of superplastic behavior of ECAP-processed and naturally aged $\mathrm{Zn}$-Al samples. For this purpose, dog-bone shaped samples having $5 \mathrm{~mm}$ gauge length and $3 \times 2 \mathrm{~mm}^{2}$ cross sectional area were extracted from the billets using wire electrical discharge machining (wire-EDM). Tensile tests were conducted at different strain rates ranging between $1 \times 10^{-5} \mathrm{~s}^{-1}$ and $1 \times 10^{-1} \mathrm{~s}^{-1}$ using Instron-3382 electro-mechanical load frame with a video type extensometer. Test samples were polished before the tensile tests, and at least three tests were conducted at each strain rates to verify the repeatability of the results.

\section{Results and Discussion}

TEM micrographs representing the microstructures of the ECAP-processed $\mathrm{Zn}$-Al alloys are shown in Fig. 1. In TEM micrographs, bright contrast corresponds to the Al-rich $\alpha$-phase while dark contrast shows the $\mathrm{Zn}$-rich $\eta$-phase. It is clear that two-step ECAP process resulted in a quite significant grain refinement in $\mathrm{Zn}-22 \mathrm{Al}$, and an ultrafine-grained (UFG) microstructure with equiaxed grains was observed after that process (Fig. 1a). Also, the microstructure consists of well-defined grain boundaries. Besides, distribution of both $\alpha$ - and $\eta$-phases are quite homogeneous throughout the microstructure. Such a microstructural feature brought about the formation of mostly $\alpha / \eta$ and $\eta / \eta$ type phase boundaries. Mean grain size of the alloy was determined as $200 \mathrm{~nm}$ from the TEM micrograph using linear intercept method. Microstructure of the ECAP-processed $\mathrm{Zn}-0.3 \mathrm{Al}$ alloy consists of FG equiaxed $\eta$-phase grains, separated from each other by well-defined grain boundaries, and nanosized $\alpha$-phase particles (Fig. 1b). Spherical $\alpha$-phase particles distributes homogeneously in the microstructure. Mean grain size of the matrix phase of $\eta$-grains were measured to be $\sim 1.3 \mu \mathrm{m}$, while the size of $\alpha$-phase particles changes between $50 \mathrm{~nm}$ and $200 \mathrm{~nm}$.

Fig. 2a shows the TEM micrograph representing the microstructure of $\mathrm{Zn}-22 \mathrm{Al}$ alloy after natural aging for 300 days. Natural aging for 300 days resulted in some grain growth, and grain size of the alloy became $\sim 500 \mathrm{~nm}$. SEM micrograph showing the microstructure of that alloy after long-term natural aging for 1100 days are given in Fig. 2b. In contrast to TEM micrographs, bright and darks contrasts in the SEM images represent $\eta$ - and $\alpha$-phases, respectively. Grain growth after very long-term aging for 1100 days is more significant comparing to 300 days aging, and grain size increased up to $\sim 1 \mu \mathrm{m}$ after that aging period. Grain size of the alloy can still be considered small regarding the so long-term natural aging of 1100 days. This behavior of UFG alloy may be attributed to its two-phase structured eutectoid composition. Since $\mathrm{Zn}-22 \mathrm{Al}$ alloy has two phases in its microstructure, $\alpha$ - and $\eta$-phases prevent the excessive growth of each other and contribute the formation of more stable microstructure.

From the TEM micrographs given in Fig. 3a, natural aging for 300 days brought about $3.0 \mu \mathrm{m}$ grain sized microstructure in $\mathrm{Zn}-0.3 \mathrm{Al}$ alloy. Regarding the ECAP-processed microstructure of the alloy, it is clear that grain boundaries are more evident after 300 days aging at RT. Furthermore, grain boundaries broadened and, as indicated by the arrows
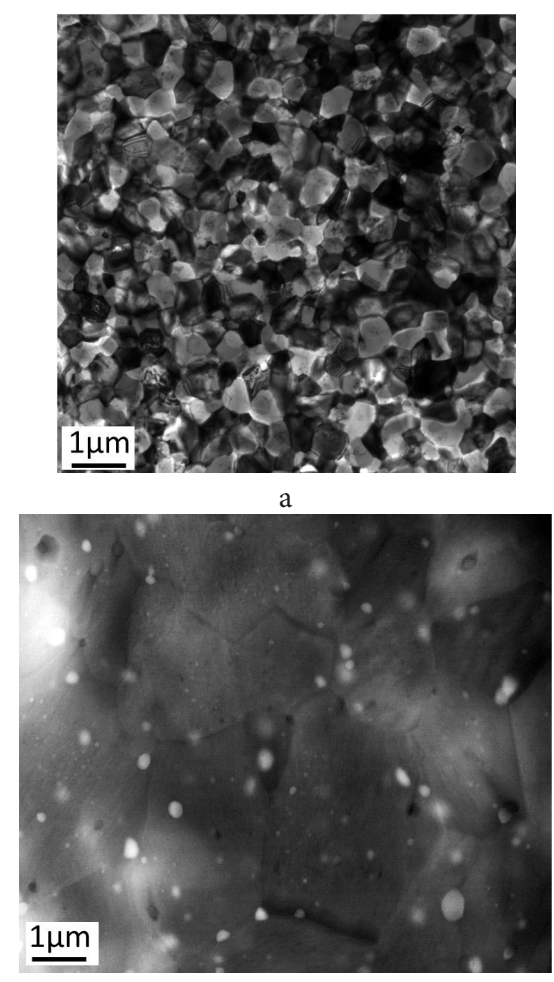

b

Fig. 1. TEM micrographs showing the initial ECAP-processed microstructures of $\mathrm{Zn}-22 \mathrm{Al}$ (a) and $\mathrm{Zn}-0.3 \mathrm{Al}$ (b) alloys [8]. 


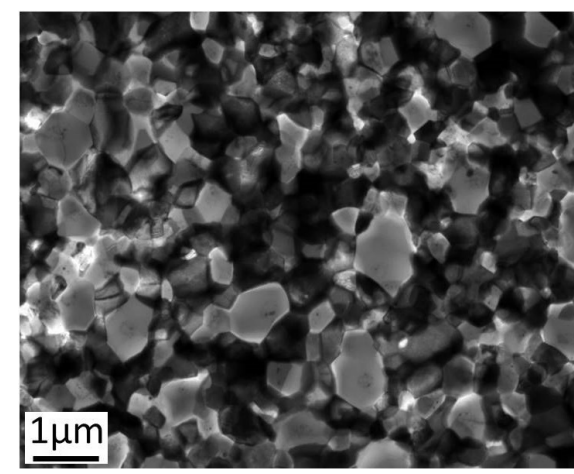

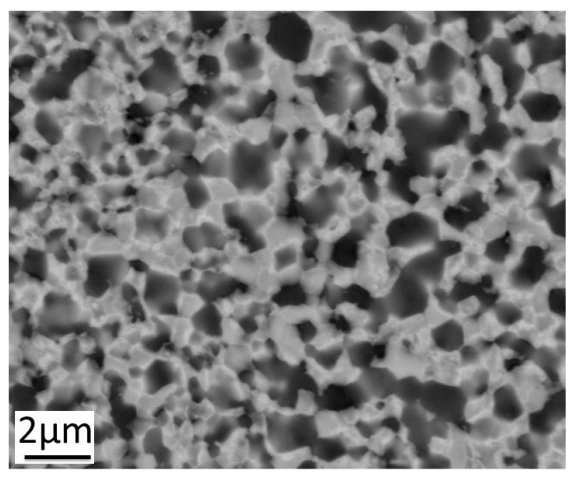

b

Fig. 2. The micrographs showing the naturally aged microstructures of $\mathrm{Zn}-22 \mathrm{Al}$ alloy: TEM micrograph after natural aging for 300 days (a) and SEM micrograph after natural aging for 1100 days (b).

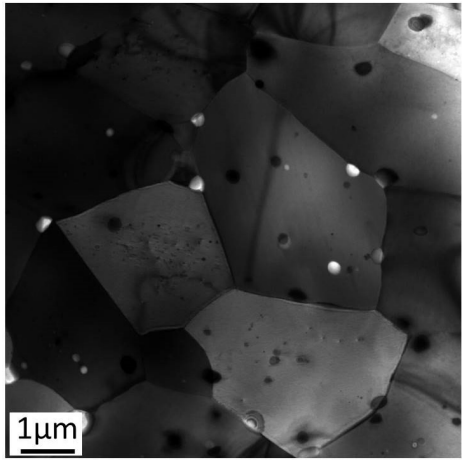

a

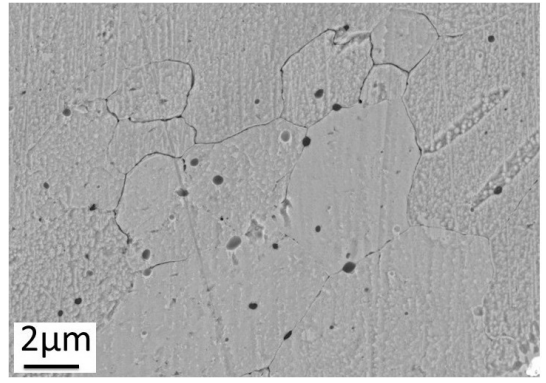

C

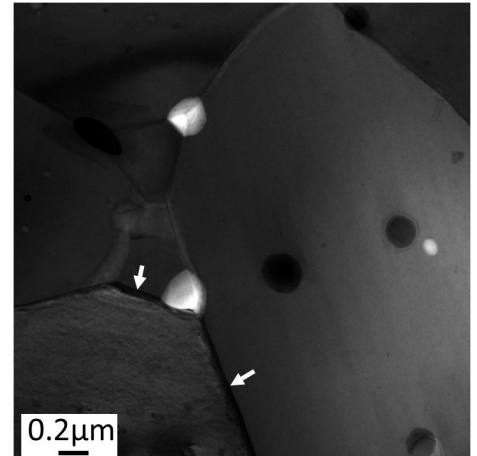

$\mathrm{b}$

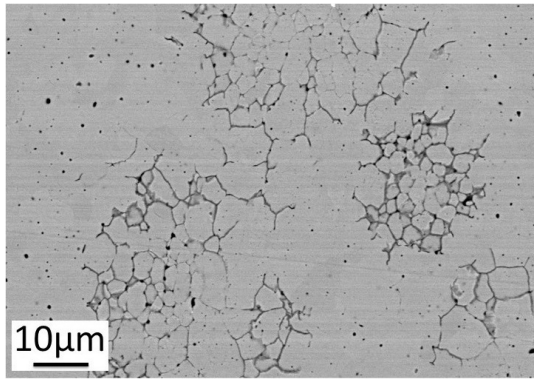

$\mathrm{d}$

Fig. 3. The micrographs showing the microstructure of naturally aged $\mathrm{Zn}-0.3 \mathrm{Al}$ alloy: TEM micrograph after natural aging for 300 days (a,b) and SEM micrograph after natural aging for 1100 days $(c, d)$.

in Fig. 3b, quite distinct gaps occurred between the grains. SEM micrographs of $\mathrm{Zn}-0.3 \mathrm{Al}$ alloy after long-term natural aging for 1100 days are shown in Figs. 3c, 3d. While Fig. 3c shows the etched microstructure of the alloy, Fig. 3d was taken from the sample just after the polishing process without etching. Significant grain growth occurred in the alloy and the mean grain size of the alloy was measured as $\sim 5.0 \mu \mathrm{m}$ from Figs. 3c, 3d. Similar to TEM microstructure of 300 days-aged alloy, distinct gaps can be seen in the SEM microstructure of the alloy after 1100 days aging. Furthermore, some of the grain boundaries are quite evident on the scanned microstructure even without etching (Fig. 3d). Regarding the TEM and SEM images given in Figs. $3 a-3 d$, it can be said that grain boundary corrosion occurred in dilute $\mathrm{Zn}-0.3 \mathrm{Al}$ alloy during the natural aging process. Because the distinct grain boundaries with gaps are the characteristic appearances of grain boundary corrosion [27]. Grain boundary corrosion in dilute $\mathrm{Zn}-\mathrm{Al}$ alloys was also reported in some previous studies, and it was stated that it was caused by $\mathrm{Al}$ precipitates at grain boundaries due to the galvanic action [28, 29]. Such a formation of grain boundary corrosion in $\mathrm{Zn}-0.3 \mathrm{Al}$ alloy was also confirmed in our previously published paper [30]. It was shown that distribution of $\mathrm{Al}$ atoms in naturally aged alloy is not homogeneous throughout the microstructure, and grain boundary corrosion was observed in somewhere having higher $\mathrm{Al}$ contents [30]. Thus, similar to the previous studies, the regions with higher $\mathrm{Al}$ contents were exposed to grain boundary corrosion in the present case, and the grain boundaries at these regions have a distinct and gaped appearances. It is worth to point out that such an adverse effect of natural aging process on the microstructure of $\mathrm{Zn}-22 \mathrm{Al}$ alloy is not observed due to the its dual phase eutectoid structure. Because $\mathrm{Zn}-22 \mathrm{Al}$ alloy does not have second phase Al-rich $\alpha$-particles or precipitates at grain boundaries which cause grain boundary corrosion due to the galvanic action.

Dependences of elongation to failure and tensile strength values of $\mathrm{Zn}-\mathrm{Al}$ alloys for all processed conditions with the initial strain rates are shown in Fig. 4. ECAP-processed 


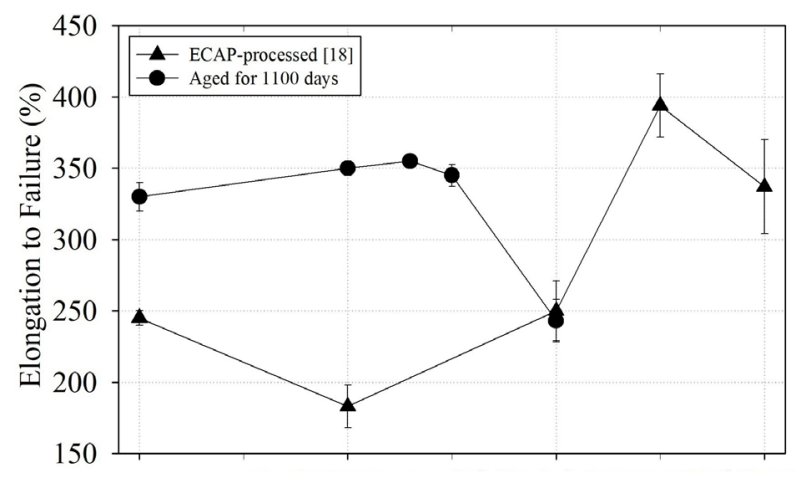

a

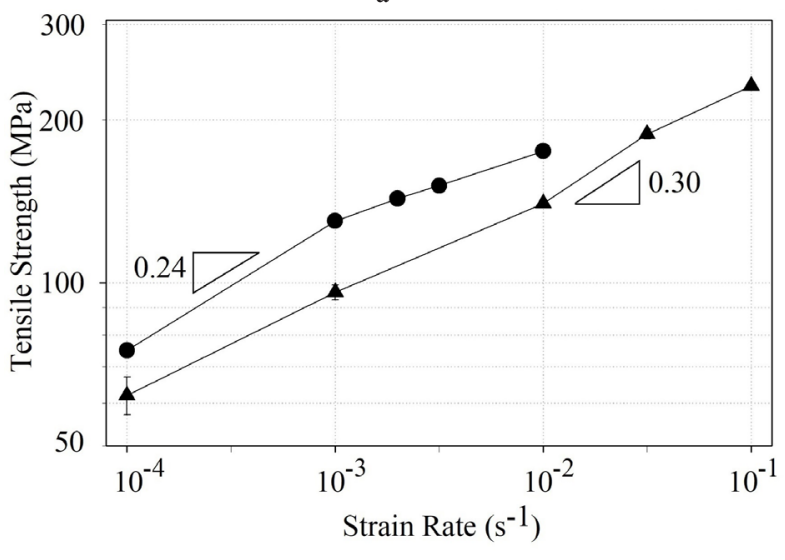

b
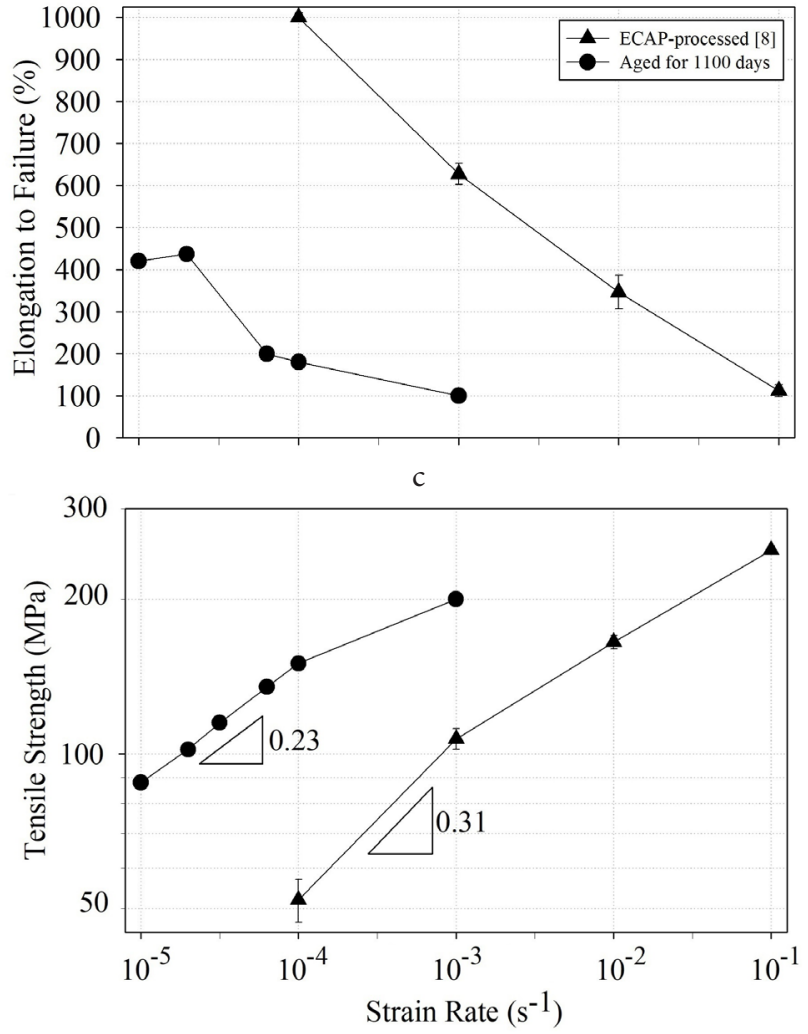

d

Fig. 4. Dependences of elongation to failure and tensile strength values of $\mathrm{Zn}-\mathrm{Al}$ alloys with the initial strain rates: $\mathrm{Zn}-22 \mathrm{Al}(\mathrm{a}, \mathrm{b})$ and $\mathrm{Zn}-0.3 \mathrm{Al}(\mathrm{c}, \mathrm{d})$ alloys.

UFG/FG samples of both alloys exhibited superplasticity at RT. Maximum superplastic elongations were achieved as $400 \%$ and $1000 \%$ for $\mathrm{Zn}-22 \mathrm{Al}$ and $\mathrm{Zn}-0.3 \mathrm{Al}$ alloys, respectively. While superplastic behavior was observed at a very high strain rate of $5 \times 10^{-2} \mathrm{~s}^{-1}$ in $\mathrm{Zn}-22 \mathrm{Al}$ alloy, $\mathrm{Zn}-0.3 \mathrm{Al}$ alloy showed the highest elongation at a reasonably lower strain rate of $1 \times 10^{-4} \mathrm{~s}^{-1}$ (Figs. $4 \mathrm{a}, 4 \mathrm{c}$ ). Natural aging at RT resulted in a limited decrease in the maximum elongation of $\mathrm{Zn}-22 \mathrm{Al}$ alloy and shifted the strain rate at which maximum elongations were observed to the lower values. Maximum elongation after natural aging for 1100 days was achieved to be $355 \%$ at $3 \times 10^{-3} \mathrm{~s}^{-1}$. In contrast to $\mathrm{Zn}-22 \mathrm{Al}$, significant decrease occurred in the maximum elongation of $\mathrm{Zn}-0.3 \mathrm{Al}$ alloy after natural aging. Maximum elongation was measured to be $435 \%$ after long-term natural aging for 1100 days. Similar to $\mathrm{Zn}-22 \mathrm{Al}$ alloy, maximum elongation was observed at lower strain rate $\left(3 \times 10^{-5} \mathrm{~s}^{-1}\right)$ comparing to the ECAPprocessed sample (Figs. 4a, 4c).

Tensile strength values of both alloys are quite sensitive to the initial strain rates in the ECAP-processed state, and increasing strain rate increased strength values of $\mathrm{Zn}-\mathrm{Al}$ alloys considerably. Strain rate sensitives ( $m$-values) were determined as 0.30 and 0.31 for $\mathrm{Zn}-22 \mathrm{Al}$ and $\mathrm{Zn}-0.3 \mathrm{Al}$ alloys, respectively, from the slopes of the tensile strengthstrain rate curves (Fig. $4 \mathrm{~b}, 4 \mathrm{~d}$ ). The achieved $m$-values are well consistent with the previous studies and high enough for occurrence of grain boundary sliding (GBS) as the main superplastic deformation mechanism in these alloys at RT [8, 13-18]. Natural aging increased the tensile strength values of both alloys. After 1100 days aging at RT, $m$-values of $\mathrm{Zn}-22 \mathrm{Al}$ and $\mathrm{Zn}-0.3 \mathrm{Al}$ alloy were determined as 0.24 and 0.23 , respectively.

High superplastic elongations was recorded in ECAPprocessed UFG Zn-22Al and FG Zn-0.3Al alloys at RT and high strain rates. UFG microstructure of $\mathrm{Zn}-22 \mathrm{Al}$ and FG microstructure of $\mathrm{Zn}-0.3 \mathrm{Al}$ alloys promote the GBS, the main deformation mechanism in these alloys at RT [8, 13-18], and lead to high superplastic elongations. Also, equiaxed grainy morphology of both alloys is another microstructural feature affecting the achieved elongations in a positive manner. Phase/grain boundary characteristics also affects superplastic elongation in $\mathrm{Zn}-\mathrm{Al}$ alloys. It is well known that $\alpha / \alpha, \alpha / \eta$ and $\eta / \eta$ phase boundaries have different sliding characteristics in $\mathrm{Zn}-\mathrm{Al}$ alloy and sliding is less effective in $\alpha / \alpha$ boundaries comparing two other boundary types [31-36]. Thus, limited $\alpha / \alpha$ phase boundary formation due to the homogeneously distributed phases throughout the microstructure of $\mathrm{Zn}$-22Al alloy contributes the superplastic elongation in that alloy. Furthermore, almost all of the phase/grain boundaries in $\mathrm{Zn}-0.3 \mathrm{Al}$ alloy are in the form of $\eta / \eta$ phase boundaries. Therefore, this alloy showed higher superplastic elongation than $\mathrm{Zn}-22 \mathrm{Al}$ alloy even though it has higher grain size. Finally, two-phase microstructure in $\mathrm{Zn}-22 \mathrm{Al}$ alloy and second phase $\alpha$-particles in $\mathrm{Zn}-0.3 \mathrm{Al}$ alloy prevent excessive grain growth during the superplastic deformation of these alloys at RT and promotes achieved elongations. More detailed analysis on the microstructural reasons of high superplastic elongations in $\mathrm{Zn}-22 \mathrm{Al}$ and $\mathrm{Zn}-0.3 \mathrm{Al}$ alloys can be found in our previously published papers $[8,18]$. 
Grain growth due to the natural aging decreased maximum elongations in both alloys and shifted the strain rates at which maximum elongation were observed to the lower values. Actually this is an expected result and well consistent with the nature of superplastic behavior in metals [1]. Smaller grain size results in higher superplastic elongation at higher strain rates due to the less time for growth of internal cavities causing the failure [1]. Therefore, maximum elongations of the $\mathrm{Zn}-22 \mathrm{Al}$ and $\mathrm{Zn}-0.3 \mathrm{Al}$ alloys decreased during natural aging as a result of grain growth and were achieved at lower strain rates comparing to ECAP-processed UFG/FG samples. On the other hand, decrease in the maximum elongation of $\mathrm{Zn}-22 \mathrm{Al}$ alloy is quite low, while $\mathrm{Zn}-0.3 \mathrm{Al}$ alloy lost more than half of its superplastic elongation at the end of the natural aging period of 1100 days. Therefore, more detailed analyses were performed on the naturally aged $\mathrm{Zn}-0.3 \mathrm{Al}$ alloy sample. Polished tensile test sample of the alloy was strained up to $10 \%$ elongation and surface of the sample was examined with SEM. Then the same sample was tensioned up to $30 \%$ total elongation and SEM analyses were performed again on the sample surface. Representative SEM images obtained from these analyses are given in Fig. 5. It is clear that some microcracks initiate at the corroded grain boundaries of $\mathrm{Zn}-0.3$ Alalloy after $10 \%$ elongation (Figs. 5a, 5b), and these microcracks attain large sizes when the elongation is increased to $30 \%$ (Figs. $5 \mathrm{c}, 5 \mathrm{~d}$ ). These results show that corroded grain boundaries result in cavity nucleation during the tensile tests, and some of these cavities attain large sizes and cause premature failure. In consequence, more significant decrease in elongation to failure of $\mathrm{Zn}-0.3 \mathrm{Al}$ alloy occurred comparing to $\mathrm{Zn}-22 \mathrm{Al}$ alloy.

\section{Conclusions}

In this study, the effect of long-term natural aging on the microstructure and RT superplastic behavior of UFG $\mathrm{Zn}-22 \mathrm{Al}$ and FG Zn-0.3Al alloys processed by ECAP were investigated. The main results and conclusions can be summarized as follows:

1. Application of ECAP results in a significant decrease in the grain sizes of $\mathrm{Zn}-\mathrm{Al}$ alloys, and mean grain sizes of $\mathrm{Zn}-22 \mathrm{Al}$ and $\mathrm{Zn}-0.3 \mathrm{Al}$ alloys decrease to about $200 \mathrm{~nm}$ and $1300 \mathrm{~nm}$, respectively.

2. ECAP-processed UFG/FG samples show superplastic behavior at RT. Maximum elongations were achieved to be $400 \%$ and $1000 \%$ with the $m$-values of 0.30 and 0.31 for $\mathrm{Zn}-22 \mathrm{Al}$ and $\mathrm{Zn}-0.3 \mathrm{Al}$ alloys, respectively.

3. Long-term natural aging results in grain growth in both alloys. Grain sizes of $\mathrm{Zn}-22 \mathrm{Al}$ alloy were measured to be $500 \mathrm{~nm}$ and $1 \mu \mathrm{m}$ after natural aging treatments for 300 days and 1100 days, respectively. Grain size of $\mathrm{Zn}-0.3 \mathrm{Al}$ alloy increased up to $\sim 5 \mu \mathrm{m}$ at the end of the long-term natural aging period of 1100 days.

4. Natural aging decreases elongation to failure in both alloys. Decrease in the maximum elongation of $\mathrm{Zn}-22 \mathrm{Al}$ alloy is quite low, and the alloy still exhibites 355\% elongation after 1100 days natural aging. On the other hand, $\mathrm{Zn}-0.3 \mathrm{Al}$ alloy loses more than half of its superplastic elongation and exhibites an elongation to failure of about $435 \%$ at the end of the natural aging period of 1100 days.
5. Microstructural analyses show that grain boundary corrosion occurred in dilute $\mathrm{Zn}-0.3 \mathrm{Al}$ alloy during the natural aging process. Corroded grain boundaries result in cavity nucleation during the tensile tests and some of these cavities attain large sizes and cause premature failure. In consequence, more significant decrease in elongation to failure of $\mathrm{Zn}-0.3 \mathrm{Al}$ alloy occurrs as compared to $\mathrm{Zn}-22 \mathrm{Al}$ alloy.
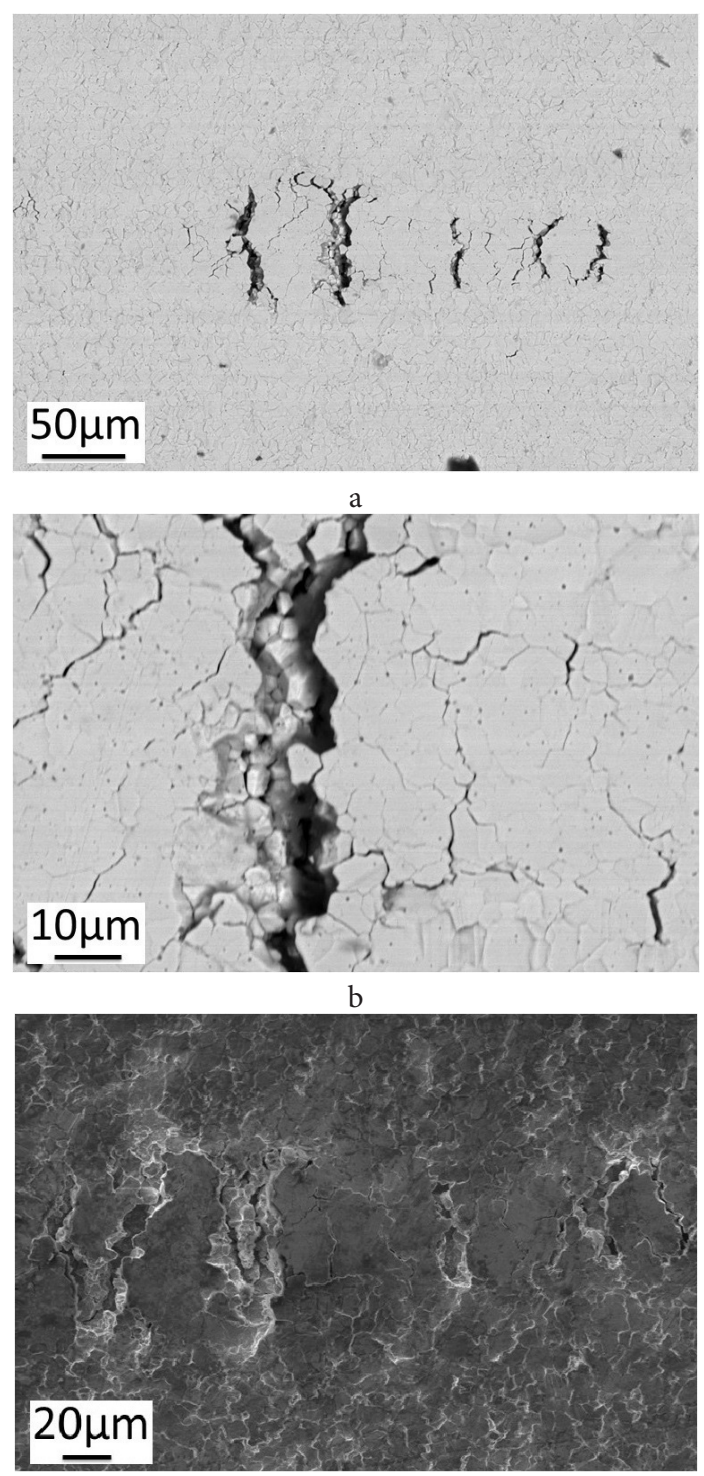

c

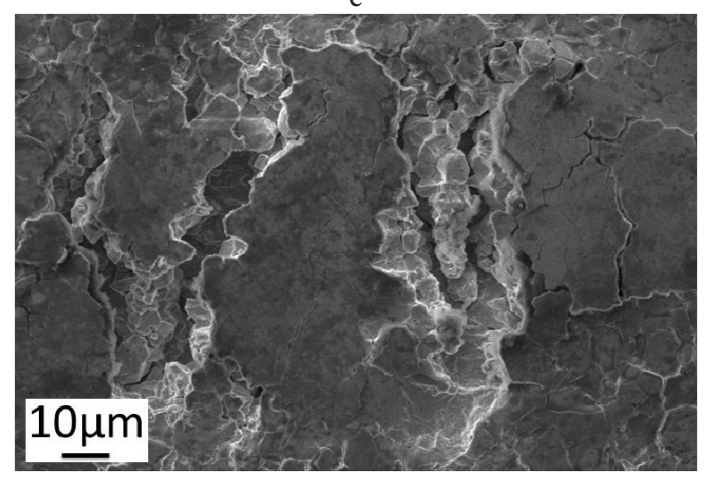

d

Fig. 5. Surface appearances of the tensile tested sample of naturally aged $\mathrm{Zn}-0.3 \mathrm{Al}$ alloy after straining up to: $10 \%(\mathrm{a}, \mathrm{b})$ and $30 \%(\mathrm{c}, \mathrm{d})$. 
Acknowledgements. The authors are grateful to Prof. ZheFeng Zhang (Chinese Academy of Sciences) for his helpful aids on TEM analysis. This research was partially supported by Scientific Research Projects of Karadeniz Technical University, Turkey, under Grant No: 10501. Dr. G. Purcek was also supported by The World Academy of Sciences (TWAS) under the Visiting Researchers program of TWAS-UNESCO Associateship Scheme.

\section{References}

1. M. Kawasaki, T. G. Langdon. J. Mater. Sci. 42, 1782 (2007). DOI: $10.1007 / \mathrm{s} 10853-006-0954-2$

2. T.G. Langdon. J. Mater. Sci. 44, 5998 (2009). DOI: $10.1007 / \mathrm{s} 10853-009-3780-5$

3. T.H. Alden. Trans. AIME. 236, 1633 (1966).

4. R. C. Gifkins. J. Inst. Met. 95, 373 (1967).

5. M. M. I. Ahmed, T. G. Langdon. J. Mater. Sci. Letters. 2, 59 (1983). DOI: 10.1007/BF00725431

6. K. Edalati, T. Masuda, M. Arita, M. Furui, X. Sauvage, Z. Horita, R.Z. Valiev. Sci. Rep. 7, 2662 (2017). DOI: $10.1038 / \mathrm{s} 41598-017-02846-2$

7. T.K. Ha, J.R. Son, W.B. Lee, C.G. Park, Y.W. Chang. Mater. Sci.Eng. A. 307, 98 (2001). DOI: 10.1016/S0921-5093(00)01952-3

8. M. Demirtas, G. Purcek, H. Yanar, Z.J. Zhang, Z.F. Zhang. Mater. Sci.Eng. A. 644, 17 (2015). DOI: 10.1016/j.msea.2015.07.04117-24

9. P. Málek, P. Lukáč. Czechoslov. J. Phys. B. 36, 498 (1986).

10. M. Demirtas, G. Purcek, H. Yanar, Z.J. Zhang, Z.F. Zhang. J. Alloy. Compd. 623, 213 (2015). DOI: 10.1016/j.jallcom.2014.10.111

11. S. H. Xia, J. Wang, J.T. Wang, J. Q. Liu. Mater. Sci. Eng. A. 493, 111 (2008). DOI: 10.1016/j.msea.2007.07.100

12. T. Tanaka, K. Makii, A. Kushibe, M. Kohzu, K. Higashi. Scr. Mater. 49, 361 (2003). DOI: 10.1016/S1359-6462(03)00328-2

13. T. Uesugi, M. Kawasaki, M. Ninomiya, Y. Kamiya, Y. Takigawa, K. Higashi. Mater. Sci.Eng. A. 645, 47 (2015). DOI: 10.1016/j.msea.2015.07.087

14. T. Tanaka, K. Higashi. Mater. Trans. 45, 1261 (2004). DOI: 10.2320/matertrans.45.1261

15. P. Kumar, C. Xu, T. G. Langdon. Mater. Sci. Eng. A. 429, 324 (2006). DOI: 10.1016/j.msea.2006.05.044

16. Y. Huang, T. G. Langdon. J. Mater. Sci. 37, 4993 (2002). DOI: $10.1023 / \mathrm{A}: 1021071228521$

17. C. F. Yang, J.H. Pan, M.C. Chuang. J. Mater. Sci. 43, 6260 (2008). DOI: 10.1007/s10853-008-2909-2

18. M. Demirtas, G. Purcek, H. Yanar, Z.J. Zhang,
Z.F. Zhang. Mater. Sci.Eng. A. 620, 233 (2014). DOI: 10.1016/j.msea.2014.09.114

19. M. Demirtas, G. Purcek, H. Yanar, Z.J. Zhang, Z.F. Zhang. J. Alloy. Compd. 663, 775 (2016). DOI: $10.1016 /$ j.jallcom.2015.12.142

20. T. Tanaka, K. Makii, H. Ueda, A. Kushibe, M. Kohzu, K. Higashi. Int. J. Mech. Sci. 45, 1599 (2003). DOI: 10.1016/j.ijmecsci.2003.12.001

21. T. Tanaka, S. W. Chung, L. F. Chaing, K. Makii, A. Kushibe, M. Kohzu, K. Higashi. Mater. Trans. 45, 2542 (2004). DOI: $10.2320 /$ matertrans.45.2542

22. T. Tanaka, S. W. Chung, L. F. Chaing, K. Makii, A. Kushibe, M. Kohzu, K. Higashi. Mater. Sci. Eng. A. 410-411, 109 (2005). DOI: 10.1016/j.msea.2005.08.115

23. N.X. Zhang, M. Kawasaki, Y. Huang, T. G. Langdon. IOP Conf. Ser.: Mater. Sci. Eng. 63, 1 (2014). DOI: $10.1088 / 1757-899 X / 63 / 1 / 012126$

24. M. Demirtas, G. Purcek, H. Yanar, Z. J. Zhang, Z.F. Zhang. Mater. Sci. Forum 320, 838 (2016). DOI: 10.4028/www.scientific.net/MSF.838-839.320

25. P. Málek, P. Lukáč, J. Suchánek. Czechoslov. J. Phys. B. 37, 729 (1987). DOI: 10.1007/BF01604797

26. O.A. Kaibyshev. Sverkhplastichnost' Promyshlennykh Splavov (Superplasticity of Commercial Alloys). Moscow, Metallurgia (1984) 264 p. (in Russian)

27. X.Y. Liu, M.J. Li, F. Gao, S.X. Liang, X.L. Zhang, H.X. Cui. J. Alloy. Compd. 639, 263 (2015). DOI: $10.1016 /$ j.jallcom.2015.03.174

28. L. P. Devillers, P. Niessen. Corros. Sci. 16, 243 (1976). DOI: 10.1016/0010-938X(76)90050-0

29. T. Jayakumar, D. K. Bhattacharya, B. Raj, P. Rodriguez. Intergranular corrosion failure in $\mathrm{Zn}$ - $\mathrm{Al}$ alloy solenoid valve seats, in: K.A. Esakul (Ed.), Handbook of Case Histories in Failure Analysis, 1 ASM International (1992).

30. M. Demirtas, M. Kawasaki, H. Yanar, G. Purcek. Mater. Sci.Eng. A. 730, 73 (2018). DOI: 10.1016/j.msea.2018.05.104

31. P. Shariat, R. B. Vastava, T. G. Langdon. Acta Metall. 30, 285 (1982). DOI: 10.1016/0001-6160(82)90068-2

32. P. Kumar, C. Xu, T.G. Langdon. Mater. Sci. Eng. A. 410 - 411, 447 (2005). DOI: 10.1016/j.msea.2005.08.092

33. H. Naziri, R. Pearce, M. R. Brown, K. F. Hale. Acta Metall. 23, 489 (1975). DOI: 10.1016/0001-6160(75)90088-7

34. I. I. Novikov, V.K. Portnoy, T.E. Terentieva. Acta Metall. 25, 1139 (1977). DOI: 10.1016/0001-6160(77)90201-2

35. M. Kawasaki, T. G. Langdon. Mater. Trans. 49, 84 (2008). DOI: 10.2320/matertrans.ME200720

36. M. Kawasaki, T. G. Langdon. Mater. Sci. Eng. A. 503, 48 (2009). DOI: 10.1016/j.msea.2008.04.081 